Grand Valley State University

ScholarWorks@GVSU

\title{
Mid-Spring Burning Reduces Spotted Knapweed and Increases Native Grasses during a Michigan Experimental Grassland Establishment
}

\author{
Neil W. MacDonald \\ Grand Valley State University, macdonan@gvsu.edu \\ Brian T. Scull \\ Annis Water Resources Institute \\ Scott R. Abella \\ Northern Arizona University
}

Follow this and additional works at: https://scholarworks.gvsu.edu/biopeerpubs

Part of the Biology Commons, and the Plant Biology Commons

\section{ScholarWorks Citation}

MacDonald, Neil W.; Scull, Brian T.; and Abella, Scott R., "Mid-Spring Burning Reduces Spotted Knapweed and Increases Native Grasses during a Michigan Experimental Grassland Establishment" (2007). Peer Reviewed Publications. 1.

https://scholarworks.gvsu.edu/biopeerpubs/1

This Article is brought to you for free and open access by the Biology Department at ScholarWorks@GVSU. It has been accepted for inclusion in Peer Reviewed Publications by an authorized administrator of ScholarWorks@GVSU. For more information, please contact scholarworks@gvsu.edu. 
The definitive version is available at www.blackwell-synergy.com

Mid-Spring Burning Reduces Spotted Knapweed and Increases Native Grasses During a Michigan Experimental Grassland Establishment

\author{
Neil W. MacDonald ${ }^{1,2}$, Brian T. Scull ${ }^{3}$, and Scott R. Abella ${ }^{4}$ \\ ${ }^{1}$ Natural Resources Management Program, Biology Department, Grand Valley State \\ University, Allendale, MI 49401-9403, U.S.A. \\ ${ }^{2}$ Address correspondence to N.W. MacDonald, email macdonan@gvsu.edu \\ ${ }^{3}$ Annis Water Resources Institute, Grand Valley State University, Muskegon, MI 49441, \\ U.S.A. \\ ${ }^{4}$ Ecological Restoration Institute, Northern Arizona University, Flagstaff, AZ 86011- \\ 5017, U.S.A.
}

Submitted to Restoration Ecology

October 17, 2005

Final Version

$3 / 9 / 06$

Published in Restoration Ecology 15(1):118-128 March 2007 


\begin{abstract}
Infestations of the exotic perennial Centaurea maculosa Lam. (spotted knapweed) hinder the restoration and management of native ecosystems on droughty, infertile sites throughout the Midwestern United States. We studied the effects of annual burning on knapweed persistence on degraded, knapweed-infested gravel-mine spoils in western Michigan. Our experiment included 48, 4- $\mathrm{m}^{2}$ plots seeded to native warm-season grasses in 1999 using a factorial arrangement of initial herbicide and fertility treatments. Beginning in 2003, we incorporated fire as an additional factor and burned half of the plots in late April or May for three years (2003-2005). Burning increased the dominance of warm-season grasses and decreased both biomass and dominance of knapweed in most years. Burning reduced adult knapweed densities in all three years of the study, reduced seedling densities in the first two years, and reduced juvenile densities in the last two years. Knapweed density and biomass also declined on the unburned plots through time, suggesting that warm-season grasses may effectively compete with knapweed even in the absence of fire. By the end of the study, mean adult knapweed densities on both burned $\left(0.4 \mathrm{~m}^{-2}\right)$ and unburned plots $\left(1.3 \mathrm{~m}^{-2}\right)$ were reduced to levels where the seeded grasses should persist with normal management, including the use of prescribed fire. These results support the use of carefully timed burning to help establish and maintain fire-adapted native plant communities on knapweed-infested sites in the Midwest by substantially reducing knapweed density, biomass, and seedling recruitment, and by further shifting the competitive balance toward native warm-season grasses.
\end{abstract}


Key words: Centaurea maculosa, spotted knapweed, native grasses, warm-season grasses, prescribed burning, grassland establishment, gravel mine spoils

\section{Introduction}

Extensive areas of abandoned agricultural lands, remnant prairies, and oak ecosystems in the upper Midwest have been invaded by Centaurea maculosa Lam. (spotted knapweed), an exotic perennial that also infests many other areas of North America. Spotted knapweed hinders the maintenance and restoration of native plant communities because it forms monotypic stands on susceptible sites (Watson \& Renney 1974; Sheley et al. 1998; DiTomaso 2000). Knapweed forms persistent infestations because of the combined effects of deep taproots that allow it to compete on droughty sites, prolific seeding (Schirman 1981; Jacobs \& Sheley 1998), long-term viability of seeds in the soil (Davis et al. 1993), allelopathic effects on other plants (Ridenour \& Callaway 2001; Hierro \& Callaway 2003), mycorrhizal interactions that may favor spotted knapweed (Marler et al. 1999), and competitive nutrient uptake (Callaway \& Aschehoug 2000; Herron et al. 2001). Knapweed is less likely to invade or resurge on the droughty, infertile sites susceptible to knapweed infestation if competition from the native plant community remains high (Story et al. 1989; Kennett et al. 1992; Lindquist et al. 1996; Sheley et al. 1999).

In the western United States, communities of cool-season grasses are susceptible to knapweed infestation (e.g., Tyser \& Key 1988; Tyser et al. 1998; Ridenour \& Callaway 2001), apparently as a result of allelopathic inhibition (Perry et al. 2005) combined with a phenology that does not compete with that of spotted knapweed. In 
contrast, Midwestern warm-season grasses actively grow throughout the summer, have extensive root systems that reduce available $\mathrm{N}$ to low levels (Tilman \& Wedin 1991), and readily establish on dry, disturbed sites (Gaffney \& Dickerson 1987). These observations suggest that these large native grasses should help constrain knapweed invasion or resurgence in restored warm-season grasslands (Bakker \& Wilson 2004). While knapweed can be controlled with herbicides (e.g., Jacobs \& Sheley 1999; Jacobs et al. 2000; Sheley et al. 2000; Sheley et al. 2001), herbicide treatments may not be compatible with maintaining diversity in restored grasslands or remnant prairies and oak ecosystems (Packard \& Mutel 1997). Fire originally was a natural phenomenon in such communities (Wolf 2004), however, and offers promise for knapweed control in these and similar fire-adapted ecosystems (Abella \& MacDonald 2000; MacDonald et al. 2001; Emery \& Gross 2005). Before 2000, published studies of burning effects on spotted knapweed were rare, and generalizations on the use of fire as a control method were based on either limited data (Watson \& Renney 1974; Sheley et al. 1998) or anecdotal reports (Renney \& Hughes 1969).

Recently, Abella and MacDonald (2000) demonstrated that heating spotted knapweed seeds at temperatures simulating those experienced in prescribed burns reduced germination significantly. MacDonald et al. (2001) reported that burning before and one or two weeks after seed germination significantly reduced both germination and survival of knapweed seedlings, suggesting that spring burns timed to decrease germination or to kill recently-emerged knapweed seedlings would reduce seedling recruitment. Emery et al. (2003) reported that July burns decreased spotted 
knapweed seedling establishment, juvenile abundance, and adult flowering more than either April or October burns. Subsequently, Emery and Gross (2005) concluded that annual summer burning was the most effective approach for reducing knapweed population growth in four prairie remnants in southwestern Michigan. Timing of burning, however, is important because spring burns encourage late-flowering warmseason grasses and forbs, while mid-summer burns may reduce their dominance (Ewing \& Engle 1988; Howe 1994; 1995).

Our study site, the Bass River Recreation Area (Section 12, T7N R15W, Ottawa County, Michigan), was acquired by the Michigan Department of Natural Resources (MDNR) in 1994. In 1999, we established a field experiment to evaluate the feasibility of establishing native warm-season grasses as a first step toward restoring a native plant community on this spotted knapweed-infested site (MacDonald et al. 2003). While these grasses successfully established, persistence of low to moderate levels of knapweed suggested that additional management might be required to maintain warmseason grass dominance on this and similar knapweed-infested sites. Based on our preliminary studies (Abella \& MacDonald 2000; MacDonald et al. 2001), we hypothesized that burning in late April and May would reduce the density of spotted knapweed and increase the dominance of warm-season grasses. To evaluate this hypothesis, we conducted a three-year study of mid-spring burning superimposed on our existing experiment. The objectives of this study were to quantify the concurrent responses to fire of both spotted knapweed and the native warm-season grass 
community it infested, and to evaluate further the feasibility of burning as a practical knapweed control strategy in restored Midwestern warm-season grasslands.

Our study occurs on the continuum of reclamation, rehabilitation, and restoration (SERI-SPWG 2004). At our study site, native plant communities were removed and surface soils were heavily disturbed by agricultural conversion and gravel mining before the area was abandoned in the early 1980s (MacDonald et al. 2003). Similar landforms and soils along the Grand River supported mixed-oak savannas or oak-pine forests in presettlement times (Comer et al. 1995). Scattered occurrences of Schizachyrium scoparium (Michx.) Nash (little bluestem), Panicum virgatum L. (switchgrass), Sporobolus cryptandrus (Torr.) A. Gray (sand dropseed), and Lespedeza hirta (L.) Hornem (hairy bush clover), together with Quercus alba L. (white oak) and Quercus velutina Lam. (black oak) forests in the immediate vicinity, suggest that the study area once supported fire-adapted communities that included warm-season grasses and forbs. This is consistent with the historical descriptions of oak ecosystems in Michigan (Nuzzo 1986). Because of soil degradation and knapweed dominance at our study site, we deviated from attempting to restore mixed-oak savanna or forest by establishing a community composed of native warm-season grasses. This is an initial intervention to align the site on a trajectory toward recovery of native species and processes (SERI-SPWG 2004). Reducing knapweed, reestablishing native species, and restoring a historical process (fire) are key steps in manipulating this trajectory away from the current monotypic stands of spotted knapweed. 


\section{Methods and Materials}

The study site is located near the center of the 421-ha recreation area on a sandy glacial outwash terrace along the Grand River in western Michigan (43 $00^{\prime} 49^{\prime \prime} \mathrm{N}$, $\left.86^{\circ} 01^{\prime} 47^{\prime \prime} \mathrm{W}\right)$. To determine the conditions needed to establish native grasses on this degraded site, we employed a factorial arrangement of treatments in a randomized complete block design, consisting of two levels of fertility ( 0 and $12 \mathrm{Mg} \mathrm{ha}^{-1}$ municipal sewage sludge), three levels of knapweed control (no herbicide, 2,4-D, and glyphosate), and eight replications. In early May, 1999, single applications of herbicides were made at label-recommended rates (2,4-D at $0.83 \mathrm{~kg} \mathrm{ha}^{-1}$ acid equivalent, glyphosate at 11.44 $\mathrm{L} \mathrm{ha}^{-1}$ active ingredient) to the appropriate plots ( $n=16$ each). One week after herbicide application, we tilled all plots and then made a single application of sludge to the appropriate plots $(n=24)$. Sludge amendment provided nutrient application rates of 813 $\mathrm{kg} \mathrm{N} \mathrm{ha}^{-1}$ and $324 \mathrm{~kg} \mathrm{P} \mathrm{ha}^{-1}$ and significantly increased soil organic $\mathrm{C}$ concentration and available water holding capacity (MacDonald et al. 2003).

In mid-May, 1999, approximately one week after sludge application, we seeded the $482 \times 2$-m plots with the native grass mixture (proportions by weight approximately 24\% Andropogon gerardii Vitman (big bluestem), 24\% Sorghastrum nutans (L.) Nash (Indian grass), 40\% little bluestem, and 12\% switchgrass; Great Lakes region seed sources, Michigan Wildflower Farm, Portland, MI) at a rate of $6 \mathrm{~g} \mathrm{~m}^{-2}$. We sampled the plots each summer between 1999-2001 to quantify initial herbicide and fertility treatment effects on native grass establishment and spotted knapweed persistence, and have previously reported the results in detail (MacDonald et al. 2003). We made total 
counts of adult knapweed on each plot in mid-July of 2002 but otherwise allowed the plots to rest undisturbed in 2002 before burning treatments commenced in 2003. Each summer throughout the study, knapweed was controlled in $1.5-\mathrm{m}$ buffers between plots and in the surrounding 3-m experimental buffer by hand-pulling, mowing, and spot treating with 2,4-D.

Burning was incorporated as a fully crossed factor into the existing experiment. Adjacent pairs of the original blocks (six plots each) were combined, and burning was randomly assigned to one plot of each pair of the six original sludge and herbicide treatment combinations in the merged blocks. This produced a randomized complete block design with four blocks of 12 treatment combinations, with half of the 48 plots being randomly selected to be burned and half remaining unburned. The procedure we followed to incorporate the burning factor into the existing experiment included replication, randomization, independence of sampling units, and interspersion of treatments as recommended by Hurlbert (1984). Based on pre-burn three-way analyses of variance of 2001 data, adult knapweed densities $(p=0.56)$, knapweed biomass $(p=0.35)$ and dominance $(p=0.35)$, and warm-season grass biomass $(p=0.25)$ and dominance ( $p=0.55$ ), did not differ significantly between plots assigned to be burned or unburned. Adult knapweed densities, the only measurement made on the plots in the summer of 2002, also did not differ significantly $(p=0.23)$ between the plots subsequently burned $\left(1.8\right.$ adults $\left.\mathrm{m}^{-2}\right)$ or unburned $\left(2.2\right.$ adults $\left.\mathrm{m}^{-2}\right)$ beginning in 2003. There also were no significant ( $p=0.24$ to 0.98 ) interactions between burning and initial fertility or herbicide treatments for either 2001 or 2002 data. 
Between 2003 and 2005, individual $2 \times 2-\mathrm{m}$ plots were independently backburned once each year in late April to late May by MDNR personnel (Table 1). The first burn in 2003 was late in May, so warm-season grasses and knapweed were actively growing at the time of the 2003 burn and both were directly exposed to the effects of the fire. In 2004, the burn was conducted in late April, while warm-season grasses were dormant, but after knapweed had commenced its early growth. The burn in 2005, conducted in early May, occurred after knapweed had initiated growth but before substantial growth of the warm-season grasses. Mean grassy fuel loads were approximately $329 \mathrm{~g} \mathrm{~m}^{-2}$ in 2003 (estimated from 2001 data), $316 \mathrm{~g} \mathrm{~m}^{-2}$ in 2004, and $510 \mathrm{~g} \mathrm{~m}^{-2}$ in 2005 . Flame heights in 2003 , measured on photographs taken during the burn, varied from 0.6 to $0.8 \mathrm{~m}$. Fuel loads and weather conditions (Table 1) were similar in 2004, suggesting similar fire intensities in both 2003 and 2004. Both fuel loads and air temperatures were higher in 2005 , resulting in greater fire intensity than in either 2003 or 2004. Total April through August precipitation, determined from the Muskegon, Michigan National Weather Service Station, was $311 \mathrm{~mm}$ in 2003, $519 \mathrm{~mm}$ in 2004, and $197 \mathrm{~mm}$ in 2005. In comparison, thirty-year (1971-2000) normal precipitation for April through August was $369 \mathrm{~mm}$.

In mid-August of each year (2003-2005), we counted knapweed plants on four randomly located $0.1-\mathrm{m}^{2}(31.62 \mathrm{~cm} \times 31.62 \mathrm{~cm})$ quadrats per plot (one quadrat per $1 \times$ 1-m plot quarter) and classified them as seedlings (small plants with 1-3 primary leaves), juveniles (non-bolted rosettes), or adults (bolted plants with flower buds, flowers, or seed heads). We clipped, dried, and weighed all plants on the quadrats by 
major species groups (warm-season grasses, spotted knapweed, other forbs, and other grasses) as detailed in MacDonald et al. (2003). Dominance of each species group was calculated as its percent of total biomass on each plot. Quadrat sampling locations were re-randomized each year for each plot. Quadrat data on each plot were combined to produce one plot average for each variable, as recommended by Hurlbert (1984). Our sampling intensity $\left(0.4 \mathrm{~m}^{2}\right.$ sampled per $4 \mathrm{~m}^{2}$ plot, or $10 \%$ of the plot sampled per year $)$ was higher than in similar studies with larger plot sizes (e.g., Sheley \& Jacobs 1997; Emery \& Gross 2005), where sampling intensity was $1 \%$ or less. Multiplying number of plots (48) by area sampled per plot $\left(0.4 \mathrm{~m}^{2}\right)$ shows that we sampled a total area of $19.2 \mathrm{~m}^{2}$ per year, greater than similar studies with larger plot sizes but lower sampling intensities $\left(7.0-12.8 \mathrm{~m}^{2}\right)$. Burning reduced knapweed densities to very low levels on many plots in our study. This was the result of the effectiveness of the burning treatment, not an artifact of the plot size or number of quadrats sampled per plot. The combined effects of low knapweed densities and total area sampled per plot, however, may have affected the precision of our individual plot estimates to some degree.

In mid-July 2005, before late summer and fall knapweed seed dispersal, we collected one seed bank sample of the upper $5 \mathrm{~cm}$ of mineral soil in each quarter of each plot using a 4.2-cm diameter metal corer. We composited these samples on a plot basis for a total of $280 \mathrm{~cm}^{3}$ soil volume per plot. We placed the $280-\mathrm{cm}^{3}$ samples on top of $250 \mathrm{~cm}^{3}$ of sterile potting soil in $700-\mathrm{cm}^{3}$ square pots and arranged the pots in a greenhouse in the same randomized block design as in the field experiment. The greenhouse was maintained at $24^{\circ} \mathrm{C}$ without supplemental lighting, and we kept samples 
moist by daily watering. We counted and removed knapweed seedlings every 15 days during a 60-day emergence period. Of the total knapweed seedlings counted, more than 70\% emerged within the first 15 days, and 100\% emerged within 45 days.

Plot average density and biomass data were converted to a per square meter basis to facilitate comparisons using a standard areal unit, and these data were statistically analyzed in that form. All data were analyzed using the full factorial design, including two levels of burn treatment (burned and unburned), two levels of initial sludge treatment, three levels of initial herbicide treatment, and four replications, for a total of 48 independent sampling units in the experiment. Means of burn main effects presented in this paper thus are based on $n=24$ burned plots and $n=24$ unburned plots. Data were tested for equality of variance with Bartlett's test (Steel \& Torrie 1980) and for normality with Lilliefor's test using SYSTAT (Version 4, Wilkinson 1989). Data were transformed using natural logarithms (ln $\mathrm{X}+1$ if data included zeros) where necessary to meet the assumption of homogeneity of variance. Log transformations produced equality of variance in most cases, but did not produce normal distributions because of zero values on some plots. For this reason, we used non-parametric permutational multifactorial analyses of variance (Anderson 2001; McArdle \& Anderson 2001) to test for treatment effects within sampling years, and performed these analyses using PERMANOVA (Anderson 2005). We used pair-wise comparisons in PERMANOVA to determine significant differences among means where appropriate. Analyses of variance were based on Bray-Curtis dissimilarities for knapweed density data, and on Euclidean distances for biomass and dominance data 
(McArdle \& Anderson 2001). Probabilities presented are based on unrestricted permutation of raw data using 4999 permutations for each analysis. Pearson correlations, based on plot means $(n=48)$, were used to assess the degree of association among variables. Significance for all analyses was accepted at $p$ less than 0.05 (Steel \& Torrie 1980).

\section{Results}

Burning reduced seedling knapweed densities in the first two years (Fig. 1a), reduced juvenile knapweed densities in the last two years (Fig. 1b), and reduced adult knapweed densities in all three years of the study (Fig. 1c, Table 2). Average residual knapweed seed bank densities tended to be lower on burned than on unburned plots in 2005, but fire treatment effects were not significant (Fig. 1d, Table 2). Effects of fire and sludge amendment interacted for seedling and juvenile knapweed densities in 2003 (Table 2). On unburned plots, significantly more seedling (7.7 vs. $\left.2.5 \mathrm{~m}^{-2}\right)$ and juvenile (4.8 vs. $0.0 \mathrm{~m}^{-2}$ ) knapweed were present on sludge-amended plots compared to unamended plots. In contrast, burning reduced both seedling $\left(0.6 \mathrm{~m}^{-2}\right)$ and juvenile knapweed $\left(0.4 \mathrm{~m}^{-2}\right)$ densities to similar levels on both sludge-amended and unamended plots in 2003. We noted a residual effect of the original sludge treatment on seedling knapweed densities again in 2005 (Table 2), with significantly more seedling knapweed on sludge-amended plots $\left(2.5 \mathrm{~m}^{-2}\right)$ as compared to unamended plots $\left(0.4 \mathrm{~m}^{-2}\right)$. There were no significant effects of sludge treatments, however, on adult knapweed densities in any year (Table 2). There were no persistent significant interactions between the burning treatments and sludge or herbicide treatments (Table 2), indicating that burning 
reduced spotted knapweed densities across a range of initial fertility and weed control combinations. There were no residual effects of initial herbicide treatments on densities of any knapweed life stage in this study (Table 2).

Knapweed biomass was reduced by burning in all three years of the study, and knapweed dominance was reduced by burning in the first two years (Tables $3 \& 4$ ). Mid-spring burning also decreased biomass and dominance of other grasses, primarily cool-season exotics (Tables $3 \& 4$ ). Warm-season grass biomass was not adversely affected by burning in 2003 (Tables $3 \&$ 4), even though the burn occurred later in May when warm-season grasses were actively growing. In contrast, warm-season grass biomass was greater on burned plots in both 2004 and 2005, and warm-season grass dominance was significantly increased by burning in all years (Tables $3 \& 4$ ). Effects of fire and initial sludge amendments on warm-season grass dominance interacted in 2004 (Table 3). Burning producing similarly high warm-season grass dominance on both amended (94.0\%) and unamended (95.2\%) plots, while dominance on unburned plots decreased from $87.5 \%$ on unamended plots to $74.5 \%$ on sludge-amended plots While the biomass and dominance of warm-season grasses tended to be greater on herbicide-treated plots in all years (Tables $3 \& 5$ ), there were no residual sludge or herbicide effects on either biomass or dominance of spotted knapweed (Table 3). There also were no significant interactions between burning and initial sludge or herbicide treatments for biomass and dominance of spotted knapweed (Table 3). Other grass biomass and dominance was consistently greater on sludge-amended plots, and consistently lower on glyphosate-treated plots throughout the study (Table 6). While 
biomass and dominance of other forbs was greater on sludge-amended plots in 2003 (Table 3), this effect did not persist in subsequent years. Burning and herbicide effects on warm-season grass dominance and other grass biomass and dominance interacted in 2005 (Table 3). During this year, warm-season grass dominance was uniformly high on burned plots, but on unburned plots varied with herbicide treatment (Table 5). Burning and herbicide interaction effects on other grasses in 2005 (Table 6) represent a mirror image effect, with biomass and dominance being greatly reduced on burned plots, but reflecting herbicide treatment effects on unburned plots more strongly.

\section{Discussion}

Both herbicides applied in 1999 (2,4-D and glyphosate) initially reduced spotted knapweed density, biomass, and dominance (MacDonald et al. 2003), but there were no residual effects of herbicide treatments on knapweed densities, biomass, or dominance during the three years of this study (Table 2). Neither of these herbicides has residual soil activity, and lack of treatment effects on knapweed between 2003 and 2005 is similar to the short-lived effects of these herbicides noted by Rice et al. (1997) and Sheley et al. (2001). Herbicide effects also decreased as a result of gradual declines in knapweed densities on plots not treated with herbicides. Mean total knapweed densities on untreated plots declined from $28.3 \mathrm{~m}^{-2}$ to $3.3 \mathrm{~m}^{-2}$ between 2001 and 2003, while mean total knapweed densities on herbicide-treated plots varied from $5.4 \mathrm{~m}^{-2}$ to $6.8 \mathrm{~m}^{-2}$ during the same time period. In contrast, both herbicide treatments produced long-term increases in warm-season grass biomass or dominance (Table 5), and glyphosate produced long-term decreases in biomass and dominance of other grasses (Table 6). 
Sludge amendment initially decreased total knapweed densities in 1999 as a result of high competition from other forbs and cool-season grasses on sludge-treated plots (MacDonald et al. 2003). In 2003 and 2005, we found slightly increased knapweed seedling densities on sludge-amended plots (Table 2), possibly as a result of higher soil available water holding capacity on these plots (MacDonald et al. 2003). More importantly, sludge amendment had no long-term effects on knapweed adult densities, biomass, or dominance (Tables $2 \& 3$ ), but did produce increased biomass and dominance of other grasses (Tables $3 \& 6$ ). Increased competition from grasses on sludge-amended plots may help prevent adult knapweed resurgence, similar to the positive effects of higher fertility on grass competition noted by Lindquist et al. (1996). Where interactions between fire and other factors occurred (Tables $2 \& 3$ ), burning removed residual effects of sludge or herbicides by consistently reducing seedling and juvenile knapweed densities, increasing dominance of warm-season grasses, and reducing biomass and dominance of other grasses.

Our results are consistent with the conclusions of MacDonald et al. (2001), Emery et al. (2003), and Emery and Gross (2005) that carefully timed burning can help reduce knapweed densities in restored or remnant Midwestern warm-season grasslands and prairies. For example, both late April (2004) and late May (2003) burns in our study significantly reduced knapweed seedling densities (Fig. 1a), consistent with midspring burns being effective in reducing germination and killing recently-germinated seedlings (MacDonald et al. 2001). Soils under warm-season grasses are warmer and drier in burned than in unburned areas (Hulbert 1969; Peet et al. 1975; Ewing \& Engle 
1988), which may help further reduce spring knapweed seedling establishment since higher soil temperatures and lower moisture availability inhibit knapweed seed germination (Eddleman \& Romo 1988; Jacobs \& Sheley 1997). Emery et al. (2003) found that July burns reduced juvenile survival, and densities of juvenile knapweed also decreased on the spring-burned plots in our study in the last two years of the study (Fig. 1b). We found that annual mid-spring burning reduced densities of adult knapweed to less than $0.5 \mathrm{~m}^{-2}$ (Fig. 1c), a level of control that should shift the competitive balance strongly in favor of grasses (Sheley \& Jacobs 1997).

Knapweed seed bank densities on burned plots did not differ significantly from those on unburned plots (Fig. 1d), but both were well below seed bank densities of knapweed-infested sites in Montana (>1000 $\mathrm{m}^{-2}$, Davis et al. 1993). Mean seed bank densities on our plots also were below estimated seed bank densities on moderately infested, unburned remnant prairies in Michigan (300-700 $\mathrm{m}^{-2}$, assuming 50\% survival of annual seed fall in the seed bank for one year; Emery \& Gross 2005). Residual seed bank densities on our plots in 2005 were most strongly correlated with mature knapweed densities measured in 2003 ( $r=0.73, p<0.001)$, largely reflecting seed production after the initiation of burning treatments. The knapweed seed bank densities on the burned plots after three years of burning $\left(52 \mathrm{~m}^{-2}\right)$ were similar to knapweed seed bank densities (32-42 $\mathrm{m}^{-2}$ ) reported by Davis et al. (1993) after seven years of experimental suppression of seed production using annual herbicide $(2,4-\mathrm{D})$ treatments, and to the seed bank density of Centaurea solstitialis L. (yellow star thistle) that also was reduced to $52 \mathrm{~m}^{-2}$ by three years of annual burning in California (Hastings \& 
DiTomaso 1996). While data on the seed bank densities of knapweed-infested sites in the Midwest are extremely limited, the relatively low seed bank densities measured in our study are consistent with a gradual reduction of knapweed seed production following the establishment of native warm-season grasses in 1999 on these plots.

Emery and Gross (2005) found no significant effect of burning on knapweed biomass or dominance (relative abundance) for April, July, or October burns, possibly because of higher knapweed abundance, lower grassy fuel loads, and resulting lower fire intensities on their remnant prairie plots than in our study. In our study, we used burning to further reduce spotted knapweed populations that already had been diminished by the establishment of vigorous stands of native warm-season grasses (MacDonald et al. 2003), while Emery and Gross (2005) used burning to control higher populations of knapweed in degraded remnant prairies. These observations, together with those of other researchers (Watson \& Renney 1974; Sheley et al. 1998; Abella \& MacDonald 2000; MacDonald et al. 2001), suggest that knapweed densities, grassy fuel loads, burn timing, and native plant community responses interact to affect burning impacts on spotted knapweed populations.

Spring burns favor the vigorous growth of warm-season grasses (e.g., Curtis \& Partch 1950; Kucera \& Ehrenreich 1962; Howe 1995) by increasing soil temperatures, light penetration, and early-season growth rates (Peet et al. 1975; Hulbert 1988). In our study, mid-spring burning also increased the dominance of warm-season grasses and this effect was consistent across initial herbicide and fertility treatments. The dominance of warm-season grasses on both burned and unburned plots in our study, 
developing over seven growing seasons (1999-2005), in part may be a result of these grasses' ability to reduce soil nutrient availability through time (Tilman \& Wedin 1991; Wedin \& Tilman 1993; Herron et al. 2001; Suding et al 2004). Burning may further increase the competitive advantage of warm-season grasses since $\mathrm{N}$ availability can be lower in annually burned warm-season grasslands (Turner et al. 1997; Smith \& Knapp 1999). Finally, while we did not measure warm-season grass seedling mortality in the vicinity of mature knapweed plants, the warm-season grasses used in our study may not be subject to potential allelopathic inhibitions from knapweed (e.g., Callaway \& Aschehoug 2000; Ridenour \& Callaway 2001; Perry et al. 2005) in that we did observe these grasses readily volunteering and persisting in the knapweed-infested area outside of our study plots (MacDonald et al. 2003).

Annual burns in Michigan warm-season grasslands and remnant prairies have been shown to help control spotted knapweed by reducing seed germination, reducing seedling, juvenile, and adult survival, or decreasing adult flowering, with the life stage affected varying with season and intensity of the burn (MacDonald et al. 2001; Emery et al. 2003; Emery \& Gross 2005). Emery and Gross (2005), who restricted their spring burns to April, found much less pronounced effects on spotted knapweed density and biomass from their earlier spring burns than in our study where burns took place from late April to late May. Burn timing can be critical, since pre-germination and postgermination burns can have significantly different effects on subsequent knapweed seedling establishment (MacDonald et al. 2001). Emery and Gross (2005) found that July burns effectively reduced knapweed abundance and adult flowering, but summer 
burns also destroy the aboveground parts of warm-season grasses during their period of maximal growth, potentially reducing their competitive vigor and changing the composition of the native plant community (Ewing \& Engle 1988; Howe 1995; Copeland et al. 2002). In contrast, while spring burns may inhibit the growth of earlyflowering native forbs (Howe 1995), spring burns also reduce the abundance and richness of exotic plant species and have positive effects on the growth of aggressive native competitors like warm-season grasses (Smith \& Knapp 1999).

Emery and Gross (2005) used population transition matrix modeling to evaluate the effects of burning on spotted knapweed populations, and cautioned against basing decisions on the effects of a management treatment on a single life stage or community property, such as seedling recruitment, adult abundance, or relative aboveground biomass. While we did not use a population modeling approach in our study, we quantified the effects of burning on multiple knapweed life stages over a three-year period, as well as on biomass and dominance of both knapweed and competing native species. We observed reduced knapweed seedling and juvenile establishment, decreased spotted knapweed biomass and dominance, reduced adult knapweed survival, and increased competitive dominance of warm-season grasses on burned plots. All of these observations lend further support to the use of burning as a means of controlling spotted knapweed in fire-adapted communities containing warm-season grasses.

The observed multiple levels of response suggest a practical level of knapweed population suppression to a point where neither supplemental herbicide treatments nor other labor-intensive control measures would be required. If desired, additional 
reductions in spotted knapweed population densities could be accomplished by handpulling of adult plants prior to flowering (Hastings \& DiTomaso 1996; Abella 2001), carefully-timed mowing (Rinella et al. 2001), or spot-treatment with selective herbicides (Rice et al. 1997). The results of our study may be most applicable to the establishment and management of native warm-season grasses on droughty, degraded, knapweed-infested sites, since burning may produce different plant community responses on sites with different soils, species compositions, or fuel loads, as noted by Howe (1994; 1995) and suggested by the results of Emery and Gross (2005). Specifically, we observed reductions in spotted knapweed density and biomass on plots with grassy fuel loads ranging from about 300 to $500 \mathrm{~g} \mathrm{~m}^{-2}$; burning on sites with lower grassy fuel loads may be less effective.

While adult knapweed also declined through time on unburned plots in our study (Fig. 1c), burning accelerated the suppression of spotted knapweed and increased the dominance of native warm-season grasses, supporting our original hypotheses. Since residual knapweed seeds can remain dormant in the soil for years and may germinate after soil disturbance (Davis et al. 1993) or during years of abundant rainfall (Fig. 1a, 2004), continued management may be required to prevent knapweed resurgence on previously infested sites. Burning is recommended to maintain the vigor of warmseason grasses on a variety of sites (Packard \& Mutel 1997), and the results of this study suggest that carefully-timed burning also will help prevent knapweed resurgence on sites restored to warm-season grasses, avoiding repeated herbicide applications or other labor-intensive management practices. 


\section{Conclusions and Management Implications}

Our results provide additional support for the use of prescribed burns to help control spotted knapweed while restoring native warm-season grasses on degraded, knapweed-infested sites. The use of mid-spring burns also may be a feasible approach to spotted knapweed control in a variety of Midwestern fire-adapted plant communities dominated by warm-season grasses with low knapweed densities and abundant grass for fuel; expanded testing in such communities seems appropriate. In degraded or lowproductivity native plant communities with higher knapweed densities and lower grassy fuel loads, other management approaches may be needed to effectively reduce spotted knapweed abundance. While burning offers a practical approach to the control of spotted knapweed in Midwestern fire-adapted communities, burns need to be carefully timed to optimize the negative impacts on knapweed populations while producing the desired effects in the native plant communities. Our results further demonstrate that active management interventions, including establishing native warm-season grasses and burning, can realign droughty, degraded sites on trajectories away from monotypic stands of spotted knapweed to ones dominated by native species and processes.

\section{Implications for Practice}

- Annual mid-spring burning reduced spotted knapweed densities and biomass and increased native warm-season grass dominance in experimental plots seeded with a mixture of big bluestem, little bluestem, Indian grass, and switchgrass. 
- Burning impacts on knapweed populations appear to be affected by knapweed densities, grassy fuel loads, burn timing, and native plant community responses to fire.

- Our results pertain specifically to a community of warm-season grasses established on a heavily disturbed site, but burning appears to be a practical tool for use in fire-adapted plant communities with low knapweed densities and abundant warm-season grass for fuel.

- Prescribed burns should be carefully timed to optimize the negative impacts on spotted knapweed populations while producing the desired effects on native plant communities. For example, in this study late-April to late-May burns reduced knapweed and favored the growth of native warm-season grasses.

\section{Acknowledgments}

Jerry Walters, Charles Ehrlich, Ray Fahlsing, and Glenn Palmgren of the Michigan Department of Natural Resources facilitated our use of the Bass River Recreation Area. Kim Dufresne, Michigan Department of Natural Resources, supervised the prescribed burns each spring. Katherine Rieger and Michelle Lelli, Grand Valley State University Annis Water Resources Institute, helped with plant counts and biomass sampling. Brad Blake and Phil Patterson of Northern Arizona University provided greenhouse care of seed bank samples. Three anonymous reviewers and the corresponding editor provided perceptive and constructive comments on earlier drafts of this manuscript. We thank all of these individuals for their generous and invaluable assistance. 


\section{Literature Cited}

Abella, S.R. 2001. Effectiveness of different management strategies for controlling spotted knapweed in remnant and restored prairies. Ecological Restoration 19:117-118.

Abella, S.R., and N.W. MacDonald. 2000. Intense burns may reduce spotted knapweed germination. Ecological Restoration 18:203-205.

Anderson, M.J. 2001. A new method for non-parametric multivariate analysis of variance. Austral Ecology 26:32-46.

Anderson, M.J. 2005. PERMANOVA: a FORTRAN computer program for permutational multivariate analysis of variance. Department of Statistics, University of Auckland, New Zealand.

Bakker, J.D., and S.D. Wilson. 2004. Using ecological restoration to constrain biological invasion. Journal of Applied Ecology 41:1058-1064.

Callaway, R.M., and E.T. Aschehoug. 2000. Invasive plants versus their new and old neighbors: a mechanism for exotic invasion. Science 290:521-523.

Comer, P.J., D.A. Albert, H.A. Wells, B.L. Hart, J.B. Raab, D.L. Price, D.M. Kashian, R.A. Corner, and D.W. Schuen. 1995. Michigan's presettlement vegetation, as interpreted from the general land office surveys 1816-1856. Michigan Natural Features Inventory, Lansing, MI. Digital map.

Copeland, T.E., W. Sluis, and H.F. Howe. 2002. Fire season and dominance in an Illinois tallgrass prairie restoration. Restoration Ecology 10:315-323. 
Curtis, J.T., and M.L. Partch. 1950. Some factors affecting flower production in Andropogon gerardi. Ecology 31:488-489.

Davis, E.S., P.K. Fay, T.K. Chicoine, and C.A. Lacey. 1993. Persistence of spotted knapweed (Centaurea maculosa) seed in soil. Weed Science 41:57-61.

DiTomaso, J.M. 2000. Invasive weeds in rangelands: species, impacts, and management. Weed Science 48:255-265.

Eddleman, L.E., and J.T. Romo. 1988. Spotted knapweed germination response to stratification, temperature, and water stress. Canadian Journal of Botany 66:653-657.

Emery, S.M., and K.L. Gross. 2005. Effects of timing of prescribed fire on the demography of an invasive plant, spotted knapweed Centaurea maculosa. Journal of Applied Ecology 42:60-69.

Emery, S.M., K.L. Gross, and K.N. Suding. 2003. Summer burns best for controlling spotted knapweed in prairie restoration experiment (Michigan). Ecological Restoration 21:137-138.

Ewing, A.L., and D.M. Engle. 1988. Effects of late summer fire on tallgrass prairie microclimate and community composition. American Midland Naturalist 120:212-223.

Gaffney, F.B., and J.A. Dickerson. 1987. Species selection for revegetating sand and gravel mines in the Northeast. Journal of Soil and Water Conservation 42:358-361.

Hastings, M.S., and J.M. DiTomaso. 1996. Fire controls yellow star thistle in California grasslands. Restoration and Management Notes 14:124-128. 
Herron, G.J., R.L. Sheley, B.D. Maxwell, and J.S. Jacobsen. 2001. Influence of nutrient availability on the interaction between spotted knapweed and bluebunch wheatgrass. Restoration Ecology 9:326-331.

Hierro, J.L., and R.M. Callaway. 2003. Allelopathy and exotic plant invasion. Plant and Soil 256:29-39.

Howe, H.F. 1994. Response of early- and late-flowering plants to fire season in experimental prairies. Ecological Applications 4:121-133.

Howe, H.F. 1995. Succession and fire season in experimental prairie plantings. Ecology 76:1917-1925.

Hulbert, L.C. 1969. Fire and litter effects in undisturbed bluestem prairie in Kansas. Ecology 50:874-877.

Hulbert, L.C. 1988. Causes of fire effects in tallgrass prairie. Ecology 69:4658.

Hurlbert, S.H. 1984. Pseudoreplication and the design of ecological field experiments. Ecological Monographs 54:187-211.

Jacobs, J.S., and R.L. Sheley. 1997. Relationships among Idaho fescue defoliation, soil water, and spotted knapweed emergence and growth. Journal of Range Management 50:258-262.

Jacobs, J.S., and R.L. Sheley. 1998. Observation: life history of spotted knapweed. Journal of Range Management 51:665-673.

Jacobs, J.S., and R.L. Sheley. 1999. Spotted knapweed, forb, and grass response to 2,4-D and N-fertilizer. Journal of Range Management 52:482-488. 
Jacobs, J.S., R.L. Sheley, and J.R. Carter. 2000. Picloram, fertilizer, and defoliation interactions on spotted knapweed reinvasion. Journal of Range Management 53:309-314.

Kennett, G.A., J.R. Lacey, C.A. Butt, K.M. Olson-Rutz, and M.R. Haferkamp. 1992. Effects of defoliation, shading, and competition on spotted knapweed and bluebunch wheatgrass. Journal of Range Management 45:363-369.

Kucera, C.L., and J.H. Ehrenreich. 1962. Some effects of annual burning on central Missouri prairie. Ecology 43:334-336

Lindquist, J.L., B.D. Maxwell, and T. Weaver. 1996. Potential for controlling the spread of Centaurea maculosa with grass competition. Great Basin Naturalist 56:267-271.

MacDonald, N.W., P.J. Bosscher, C.A. Mieczkowski, E.M. Sauter, and B.J. Tinsley. 2001. Pre- and post-germination burning reduces establishment of spotted knapweed seedlings. Ecological Restoration 19:262-263.

MacDonald, N.W., M.T. Koetje, and B.J. Perry. 2003. Native warm-season grass establishment on spotted knapweed-infested gravel mine spoils. Journal of Soil and Water Conservation 58:243-250.

Marler, M.J., C.A. Zabinski, and R.M. Callaway. 1999. Mycorrhizae indirectly enhance competitive effects of an invasive forb on a native bunchgrass. Ecology 80:1180-1186. 
McArdle, B.H., and M.J. Anderson. 2001. Fitting multivariate models to community data: a comment on distance-based redundancy analysis. Ecology 82:290297.

Nuzzo, V.A. 1986. Extent and status of Midwest oak savanna: presettlement and 1985. Natural Areas Journal 6(2):6-36.

Packard, S., and C.F. Mutel (ed.). 1997. The tallgrass restoration handbook. Island Press, Covelo, California.

Peet, M., R. Anderson, and M.S. Adams. 1975. Effect of fire on big bluestem production. American Midland Naturalist 94:15-26.

Perry, L.G., C. Johnson, E.R. Alford, J.M. Vivanco, and M.W. Paschke. 2005. Screening of grassland plants for restoration after spotted knapweed invasion. Restoration Ecology 13:725-735.

Renney, A.J., and E.C. Hughes. 1969. Control of knapweed, Centaurea species, in British Columbia with TORDON herbicide. Down to Earth 24:6-8.

Rice, P.M., J.C. Toney, D.J. Bedunah, and C.E. Carlson. 1997. Plant community diversity and growth form responses to herbicide applications for control of Centaurea maculosa. Journal of Applied Ecology 34:1397-1412.

Ridenour, W.M., and R.M. Callaway. 2001. The relative importance of allelopathy in interference: the effects of an invasive weed on a native bunchgrass. Oecologia 126:444-450. 
Rinella, M.J., J.S. Jacobs, R.L. Sheley, and J.J. Borkowski. 2001. Spotted knapweed response to season and frequency of mowing. Journal of Range Management 54:52-56.

Schirman, R. 1981. Seed production and spring seedling establishment of diffuse and spotted knapweed. Journal of Range Management 34:45-47.

SERI-SPWG (Society for Ecological Restoration International Science and Policy Working Group). 2004. The SER international primer on ecological restoration. www.ser.org. Society for Ecological Restoration International, Tucson, AZ.

Sheley, R.L., and J.S. Jacobs. 1997. “Acceptable” levels of spotted knapweed (Centaurea maculosa) control. Weed Technology 11:363-368.

Sheley, R.L., J.S. Jacobs, and M.F. Carpinelli. 1998. Distribution, biology, and management of diffuse knapweed (Centaurea diffusa) and spotted knapweed (Centaurea maculosa). Weed Technology 12:353-362.

Sheley, R.L., J.S. Jacobs, and R.P. Velagala. 1999. Enhancing intermediate wheatgrass establishment in spotted knapweed infested rangeland. Journal of Range Management 52:68-74.

Sheley, R.L., C.A. Duncan, M.B. Halstvedt, and J.S. Jacobs. 2000. Spotted knapweed and grass response to herbicide treatments. Journal of Range Management 53:176-182.

Sheley, R.L., J.S. Jacobs, and D.E. Lucas. 2001. Revegetating spotted knapweed infested rangeland in a single entry. Journal of Range Management 54:144151. 
Smith, M.D., and A.K. Knapp. 1999. Exotic plant species in a $\mathrm{C}_{4}$-dominated grassland: invasibility, disturbance, and community structure. Oecologia 120:605-612.

Steel, R.G.D., and J.H. Torrie. 1980. Principles and procedures of statistics, 2nd edition. McGraw-Hill Book Company, New York.

Story, J.M., K.W. Boggs, and D.R. Graham. 1989. Effects of nitrogen fertilization on spotted knapweed and competing vegetation in western Montana. Journal of Range Management 42:222-225.

Suding, K.N., K.D. LeJeune, and T.R. Seastedt. 2004. Competitive impacts and responses of an invasive weed: dependencies on nitrogen and phosphorus availability. Oecologia 141:526-535.

Tilman, D., and D. Wedin. 1991. Plant traits and resource reduction for five grasses growing on a nitrogen gradient. Ecology 72:685-700

Turner, C.L., J.M. Blair, R.J. Schartz, and J.C. Neel. 1997. Soil N and plant responses to fire, topography, and supplemental $\mathrm{N}$ in tallgrass prairie. Ecology 78:1832-1843.

Tyser, R.W., and C.H. Key. 1988. Spotted knapweed in natural area fescue grasslands: an ecological assessment. Northwest Science 62:151-160.

Tyser, R.W., J.M. Asebrook, R.W. Potter, and L.L. Kurth. 1998. Roadside revegetation in Glacier National Park, U.S.A.: effects of herbicide and seeding treatments. Restoration Ecology 6:197-206.

Watson, A.K., and A.J. Renney. 1974. The biology of Canadian weeds. 6. Centaurea diffusa and C. maculosa. Canadian Journal of Plant Science 54:687-701. 
Wedin, D., and D. Tilman. 1993. Competition among grasses along a nitrogen gradient: initial conditions and mechanisms of competition. Ecological Monographs 63:199-229.

Wolf, J. 2004. A 200-year fire history in a remnant oak savanna in southeastern Wisconsin. American Midland Naturalist 152:201-213.

Wilkinson, L. 1989. SYSTAT: The system for statistics, Version 4. Evanston, IL, SYSTAT, Inc. 
Table 1. Burn-day ${ }^{a}$ weather conditions at the Bass River Recreation Area (Section 12, T7N R15W, Ottawa County, Michigan).

$\begin{array}{llll}\text { Date } & 5 / 22 / 03 & 4 / 24 / 04 & 5 / 9 / 05 \\ \text { Air temperature }\left({ }^{\circ} \mathrm{C}\right) & 16.7 & 16.1 & 26.1 \\ \text { Relative humidity }(\%) & 42 & 42 & 47 \\ \text { Wind speed }\left(\mathrm{km} \mathrm{h}^{-1}\right) & 3-10 & 13 & 8-13 \\ \text { Wind direction } & \text { west } & \text { northwest } & \text { south } \\ \text { Time of record } & 11: 17 \text { a.m. } & 1: 39 \text { p.m. } & 12: 17 \text { p.m. }\end{array}$

${ }^{a}$ Burn-day weather data recorded on-site by Kim Dufresne, Area Fire Supervisor, Michigan Department of Natural Resources. 
Table 2. Significance probabilities from permutational three-way analyses of variance for spotted knapweed and seed bank density data, Bass River Recreation Area, Ottawa County, Michigan.

\begin{tabular}{lllllllll}
\hline & \multicolumn{8}{c}{ Source of Variation } \\
Variable & Year & $\mathrm{F}^{\mathrm{a}}$ & $\mathrm{S}^{\mathrm{b}}$ & $\mathrm{H}^{\mathrm{c}}$ & $\mathrm{F} \times \mathrm{S}^{\mathrm{d}}$ & $\mathrm{F} \times \mathrm{H}^{\mathrm{d}}$ & $\mathrm{S} \times \mathrm{H}^{\mathrm{d}}$ & $\mathrm{F} \times \mathrm{S} \times \mathrm{H}^{\mathrm{d}}$ \\
Adult & 2003 & $\mathbf{0 . 0 1}$ & 0.53 & 0.11 & 0.58 & 0.85 & 0.94 & 0.90 \\
Knapweed & 2004 & $<\mathbf{0 . 0 1}$ & 0.65 & 0.39 & 0.24 & 0.69 & 0.22 & 0.36 \\
& 2005 & $\mathbf{0 . 0 1}$ & 0.61 & 0.09 & 0.63 & 0.40 & 0.41 & 0.40 \\
& & & & & & & & \\
Juvenile & 2003 & 0.76 & 0.15 & 0.10 & $\mathbf{0 . 0 2}$ & 0.89 & 0.20 & 0.08 \\
Knapweed & 2004 & $\mathbf{0 . 0 3}$ & 0.07 & 0.45 & 0.23 & 0.51 & 0.47 & 0.42 \\
& 2005 & $\mathbf{0 . 0 4}$ & 0.32 & 0.15 & 0.78 & 0.50 & 0.72 & 0.89 \\
& & & & & & & & \\
Seedling & 2003 & $<\mathbf{0 . 0 1}$ & $\mathbf{0 . 0 1}$ & 0.11 & $<\mathbf{0 . 0 1}$ & 0.60 & 0.68 & 0.27 \\
Knapweed & 2004 & $\mathbf{0 . 0 3}$ & 0.76 & 0.44 & 0.98 & 0.07 & 0.33 & 0.54 \\
& 2005 & 0.48 & $<\mathbf{0 . 0 5}$ & 0.26 & 0.49 & 0.35 & 0.80 & $\mathbf{0 . 0 2}$ \\
& & & & & & & & \\
Seed bank & 2005 & 0.85 & 0.77 & 0.21 & 0.93 & 0.35 & 0.95 & 0.95 \\
& & & & & & & & \\
\hline
\end{tabular}

${ }^{\mathrm{a}} \mathrm{F}=p$-values for fire main effect, ${ }^{\mathrm{b}} \mathrm{S}=p$-values for sludge main effect, ${ }^{\mathrm{c}} \mathrm{H}=p$-values for herbicide main effect, ${ }^{\mathrm{d}} \mathrm{F} \times \mathrm{S}, \mathrm{F} \times \mathrm{H}, \mathrm{S} \times \mathrm{H}, \mathrm{F} \times \mathrm{S} \times \mathrm{H}=p$-values for interaction effects. Analysis based on Bray-Curtis dissimilarities calculated from ln-transformed data. Significant $p$-values $(<0.05)$ in bold. 
Table 3. Significance probabilities from permutational three-way analyses of variance for plant biomass and dominance data, Bass River Recreation Area, Ottawa County, Michigan.

Source of Variation

$\begin{array}{lllllllll}\text { Variable } & \text { Year } & \mathrm{F}^{\mathrm{a}} & \mathrm{S}^{\mathrm{b}} & \mathrm{H}^{\mathrm{c}} & \mathrm{F} \times \mathrm{S}^{\mathrm{d}} & \mathrm{F} \times \mathrm{H}^{\mathrm{d}} & \mathrm{S} \times \mathrm{H}^{\mathrm{d}} & \mathrm{F} \times \mathrm{S} \times \mathrm{H}^{\mathrm{d}} \\ \text { Warm-season } & 2003 & 0.90 & 0.11 & \mathbf{0 . 0 4} & 0.64 & 0.50 & 0.50 & 0.38 \\ \text { Grass } & 2004 & <\mathbf{0 . 0 1} & 0.65 & 0.06 & 0.43 & 0.26 & 0.56 & 0.23 \\ \text { Biomass } & 2005 & \mathbf{0 . 0 3} & 0.34 & \mathbf{0 . 0 2} & 0.57 & 0.80 & 0.81 & 0.46\end{array}$

$\begin{array}{lllllllll}\text { Other Grass } & 2003 & <\mathbf{0 . 0 1} & <\mathbf{0 . 0 1} & <\mathbf{0 . 0 1} & 0.16 & 0.15 & 0.79 & 0.12 \\ \text { Biomass } & 2004 & <\mathbf{0 . 0 1} & <\mathbf{0 . 0 1} & <\mathbf{0 . 0 1} & 0.85 & 0.68 & 0.93 & 0.50 \\ & 2005 & <\mathbf{0 . 0 1} & <\mathbf{0 . 0 1} & <\mathbf{0 . 0 1} & 0.73 & \mathbf{0 . 0 3} & 0.29 & 0.14\end{array}$

$\begin{array}{lllllllll}\text { Spotted } & 2003 & <\mathbf{0 . 0 1} & 0.54 & 0.13 & 0.83 & 0.80 & 0.78 & 0.84\end{array}$

$\begin{array}{lllllllll}\text { Knapweed } & 2004 & <\mathbf{0 . 0 1} & 0.62 & 0.49 & 0.46 & 0.90 & 0.15 & 0.66\end{array}$

$\begin{array}{lllllllll}\text { Biomass } & 2005 & \mathbf{0 . 0 4} & 0.88 & 0.14 & 0.88 & 0.76 & 0.40 & 0.70\end{array}$

$\begin{array}{lllllllll}\text { Other Forb } & 2003 & 0.13 & <\mathbf{0 . 0 1} & 0.16 & 0.51 & 0.59 & 0.72 & 0.15\end{array}$

$\begin{array}{lllllllll}\text { Biomass } & 2004 & 0.50 & 0.06 & 0.38 & 0.32 & 0.45 & 0.63 & 0.55\end{array}$

$\begin{array}{llllllll}2005 & 0.20 & 0.68 & 0.12 & 0.82 & 0.56 & 0.75 & 0.94\end{array}$

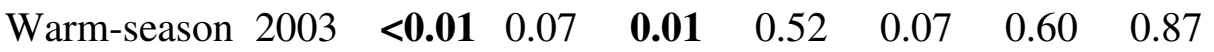

$\begin{array}{lllllllll}\text { Grass } & 2004 & <\mathbf{0 . 0 1} & \mathbf{0 . 0 2} & <\mathbf{0 . 0 1} & \mathbf{0 . 0 4} & 0.14 & 0.40 & 0.10\end{array}$

$\begin{array}{lllllllll}\text { Dominance } & 2005 & <\mathbf{0 . 0 1} & 0.11 & <\mathbf{0 . 0 1} & 0.14 & \mathbf{0 . 0 1} & 0.70 & 0.68\end{array}$

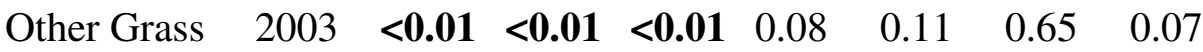

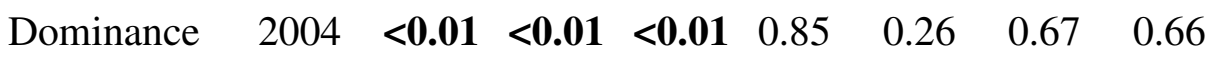

$\begin{array}{llllllll}2005 & <\mathbf{0 . 0 1} & \mathbf{0 . 0 2} & <\mathbf{0 . 0 1} & 0.60 & \mathbf{0 . 0 2} & 0.36 & 0.39\end{array}$ 


$\begin{array}{lllllllll}\text { Spotted } & 2003 & \mathbf{< 0 . 0 1} & 0.54 & 0.14 & 0.89 & 0.85 & 0.80 & 0.86 \\ \text { Knapweed } & 2004 & <\mathbf{0 . 0 1} & 0.72 & 0.49 & 0.33 & 0.95 & 0.21 & 0.57 \\ \text { Dominance } & 2005 & 0.06 & 0.88 & 0.18 & 0.92 & 0.78 & 0.45 & 0.75 \\ & & & & & & & & \\ \text { Other Forb } & 2003 & 0.39 & \mathbf{< 0 . 0 1} & 0.40 & 0.63 & 0.37 & 0.66 & 0.19 \\ \text { Dominance } & 2004 & 0.60 & 0.12 & 0.48 & 0.21 & 0.31 & 0.50 & 0.36 \\ & 2005 & 0.30 & 0.52 & 0.09 & 0.83 & 0.72 & 0.62 & 0.96\end{array}$

${ }^{\mathrm{a}} \mathrm{F}=p$-values for fire main effect, ${ }^{\mathrm{b}} \mathrm{S}=p$-values for sludge main effect, ${ }^{\mathrm{c}} \mathrm{H}=p$-values for herbicide main effect, ${ }^{\mathrm{d}} \mathrm{F} \times \mathrm{S}, \mathrm{F} \times \mathrm{H}, \mathrm{S} \times \mathrm{H}, \mathrm{F} \times \mathrm{S} \times \mathrm{H}=p$-values for interaction effects. Analyses based on Euclidean distances calculated from ln-transformed data.

Significant $p$-values $(<0.05)$ in bold. 
Table 4. Fire effects on plant biomass ${ }^{\mathrm{a}}$ and dominance ${ }^{\mathrm{b}}$ by major species groups, Bass River Recreation Area, Ottawa County, Michigan.

\begin{tabular}{lcrc} 
& \multicolumn{3}{c}{ Year } \\
Fire Treatment & 2003 & 2004 & 2005 \\
& & & \\
& & Spotted Knapweed \\
Unburned & $74.4 \mathrm{a}(12.1 \mathrm{x})$ & $30.9 \mathrm{a}(5.7 \mathrm{x})$ & $5.2 \mathrm{a}(2.1)$ \\
Burned & $7.2 \mathrm{~b}(2.5 \mathrm{y})$ & $5.7 \mathrm{~b}(1.6 \mathrm{y})$ & $0.9 \mathrm{~b}(0.5)$
\end{tabular}

Other Forbs

$\begin{array}{llll}\text { Unburned } & 6.2(1.5) & 2.2(0.5) & 1.6(0.6) \\ \text { Burned } & 3.6(1.6) & 2.5(0.5) & 0.0(0.0)\end{array}$

Other Grasses

$\begin{array}{lrlr}\text { Unburned } & 37.1 \mathrm{a}(9.5 \mathrm{x}) & 58.7 \mathrm{a}(12.8 \mathrm{x}) & 38.8 \mathrm{a}(16.1 \mathrm{x}) \\ \text { Burned } & 7.2 \mathrm{~b}(2.3 \mathrm{y}) & 16.0 \mathrm{~b}(3.3 \mathrm{y}) & 2.6 \mathrm{~b}(1.0 \mathrm{y})\end{array}$

Warm Season Grasses

$\begin{array}{llll}\text { Unburned } & 308.5(76.9 \mathrm{y}) & 376.5 \mathrm{~b}(81.0 \mathrm{y}) & 214.4 \mathrm{~b}(81.1 \mathrm{y}) \\ \text { Burned } & 301.6(93.7 \mathrm{x}) & 494.0 \mathrm{a}(94.6 \mathrm{x}) & 263.8 \mathrm{a}(98.5 \mathrm{x})\end{array}$

${ }^{\mathrm{a}}$ Biomass in $\mathrm{g} \mathrm{m}^{-2}$ and ${ }^{\mathrm{b}}$ (dominance in \%). Means followed by different letters differ significantly; a, b compare biomass means within years, $\mathrm{x}$, y compare dominance means within years. Means without letters do not differ significantly. See Table 3 for exact $p$ values. 
Table 5. Sludge, herbicide, and fire interaction effects on warm-season grass biomass ${ }^{\mathrm{a}}$ and dominance ${ }^{\mathrm{b}}$ at the Bass River Recreation Area, Ottawa County, Michigan.

\begin{tabular}{llll}
\hline & & & \\
& & \\
& & \\
Sludge Treatment & None & $2,4-\mathrm{D} \quad$ Glyphosate & Sludge Means
\end{tabular}

\begin{tabular}{lllllllll} 
& \multicolumn{7}{c}{2003} \\
None & 278 & $(82.2)$ & 316 & $(92.3)$ & 372 & $(96.0)$ & 322 & $(90.2)$ \\
Amended & 241 & $(71.1)$ & 317 & $(88.9)$ & 304 & $(83.3)$ & 288 & $(81.1)$ \\
Herbicide Means & $260 \mathrm{~b}(76.7 \mathrm{y})$ & $317 \mathrm{a}(90.6 \mathrm{x})$ & $338 \mathrm{a}(89.7 \mathrm{xy})$ & &
\end{tabular}

\begin{tabular}{lllllllll} 
& \multicolumn{8}{c}{2004} \\
None & 390 & $(85.5)$ & 426 & $(90.9)$ & 452 & $(97.7)$ & 423 & $(91.4 \mathrm{x})$ \\
Amended & 377 & $(74.1)$ & 469 & $(88.5)$ & 498 & $(90.1)$ & 448 & $(84.2 \mathrm{y})$ \\
Herbicide Means & 383 & $(79.8 \mathrm{y})$ & 448 & $(89.7 \mathrm{xy})$ & 475 & $(93.9 \mathrm{x})$ & &
\end{tabular}

\begin{tabular}{lllllllll} 
& \multicolumn{8}{c}{2005} \\
None & 170 & $(86.4)$ & 257 & $(91.8)$ & 258 & $(96.8)$ & 228 & $(91.7)$ \\
Amended & 220 & $(82.0)$ & 268 & $(90.9)$ & 262 & $(90.8)$ & 250 & $(87.9)$ \\
Herbicide Means & $195 b(84.2 y)$ & $263 a(91.4 x y)$ & $260 a(93.8 x)$ &
\end{tabular}

2005 Fire $\times$ Herbicide Interaction (dominance)

Fire Treatment

Burn Means

$\begin{array}{lllll}\text { Unburned } & 161(70.5 z) & 238(84.1 y) & 245(88.7 y) & 214(81.1 y) \\ \text { Burned } & 229(97.9 x) & 288(98.6 x) & 275(99.0 x) & 264(98.5 x)\end{array}$

${ }^{\mathrm{a}}$ Biomass in $\mathrm{g} \mathrm{m}^{-2}$ and ${ }^{\mathrm{b}}$ (dominance in \%). Means followed by different letters differ significantly; a, b compare biomass means, $\mathrm{x}, \mathrm{y}, \mathrm{z}$ compare dominance means. Means without letters do not differ significantly. See Table 3 for exact $p$-values. 
Table 6. Sludge, herbicide, and fire interaction effects on other grass biomass ${ }^{\mathrm{a}}$ and dominance $^{\mathrm{b}}$ at the Bass River Recreation Area, Ottawa County, Michigan.

\begin{tabular}{|c|c|c|c|c|}
\hline \multirow[b]{2}{*}{ Sludge Treatment } & \multirow[b]{2}{*}{ None } & \multicolumn{2}{|c|}{ Herbicide Treatment } & \multirow[b]{2}{*}{ Sludge Means } \\
\hline & & 2,4-D & Glyphosate & \\
\hline \multicolumn{5}{|c|}{2003} \\
\hline None & $18.1 \quad(4.6)$ & 11.7 (3.6) & $2.5 \quad(0.7)$ & $10.8 \mathrm{~b}(2.9 \mathrm{y})$ \\
\hline Amended & 56.9 (15.3) & $25.8 \quad(7.0)$ & $14.0 \quad(3.4)$ & $32.2 \mathrm{a}(8.6 \mathrm{x})$ \\
\hline Herbicide Means & $37.5 \mathrm{a}(9.9 \mathrm{x})$ & $18.7 \mathrm{a}(5.3 \mathrm{x})$ & $8.3 \mathrm{~b}(2.0 \mathrm{y})$ & \\
\hline \multicolumn{5}{|c|}{2004} \\
\hline None & $35.9 \quad(7.6)$ & $22.2 \quad(5.6)$ & $6.2(1.5)$ & $21.4 \mathrm{~b}(4.9 \mathrm{y})$ \\
\hline Amended & $92.2 \quad(20.8)$ & $48.8 \quad(9.5)$ & 18.6 & $53.2 \mathrm{a}(11.2 \mathrm{x})$ \\
\hline Herbicide Means & $64.0 \mathrm{a}(14.2 \mathrm{x})$ & $35.5 a(7.6 x)$ & $12.4 \mathrm{~b}(2.4 \mathrm{y})$ & \\
\hline \multicolumn{5}{|c|}{2005} \\
\hline None & $19.6 \quad(9.4)$ & $19.0 \quad(7.8)$ & $4.3 \quad(2.2)$ & $14.3 \mathrm{~b}(6.4 \mathrm{y})$ \\
\hline Amended & $40.4 \quad(17.0)$ & $23.6(9.1)$ & $17.1 \quad(6.0)$ & $27.1 \mathrm{a}(10.7 \mathrm{x})$ \\
\hline Herbicide Means & $30.0 \mathrm{a}(13.2 \mathrm{x})$ & $21.3 \mathrm{a}(8.4 \mathrm{x})$ & $10.7 \mathrm{~b}(4.1 \mathrm{y})$ & \\
\hline
\end{tabular}

2005 Fire $\times$ Herbicide Interactions

Fire Treatment

Burn Means

Unburned

$57.8 \mathrm{a}(25.4 \mathrm{w}) 39.0 \mathrm{a}(15.5 \mathrm{w}) 19.6 \mathrm{~b}(7.6 \mathrm{x})$

$38.8 \mathrm{a}(16.1 \mathrm{x})$

Burned

$2.3 \mathrm{~cd}(1.1 \mathrm{yz}) \quad 3.6 \mathrm{c}(1.4 \mathrm{y}) \quad 1.8 \mathrm{~d}(0.6 \mathrm{z})$

$2.6 \mathrm{~b}(1.0 \mathrm{y})$

${ }^{\mathrm{a}}$ Biomass in $\mathrm{g} \mathrm{m}^{-2}$ and ${ }^{\mathrm{b}}$ (dominance in \%). Means followed by different letters differ significantly; a, b, c, d compare biomass means, w, x, y, z compare dominance means. Means without letters do not differ significantly. See Table 3 for exact $p$-values. 


\section{Figure Captions}

Figure 1. Fire effects on density of spotted knapweed life stages and on residual knapweed seed bank density, Bass River Recreation Area, Ottawa County, Michigan. Error bars represent standard errors of the mean. Within-year fire effects significant at $* p<0.05$ or $* * p<0.01 ;$ n.s. $=$ fire effects not significant. See Table 2 for exact $p$-values. 


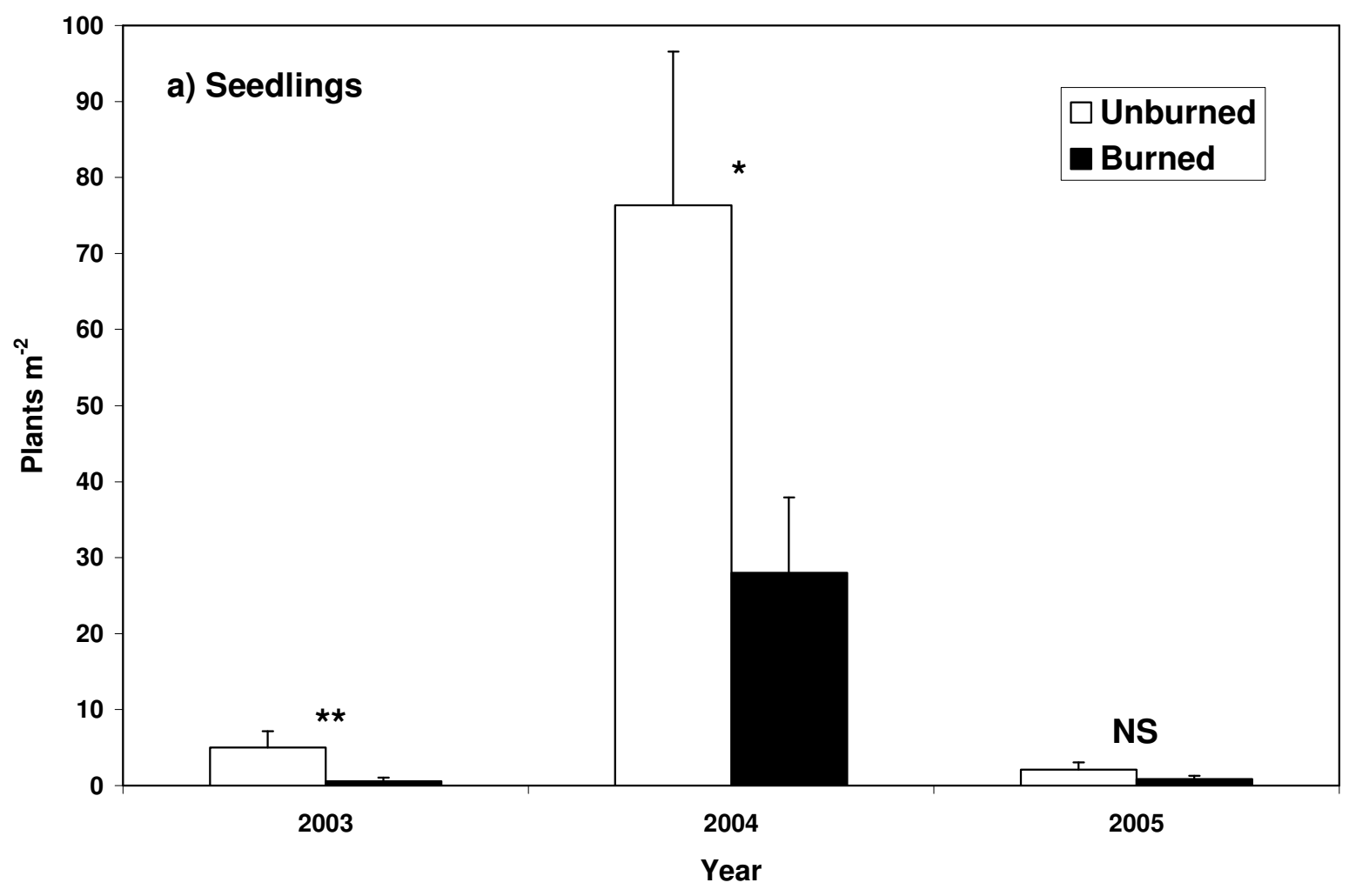




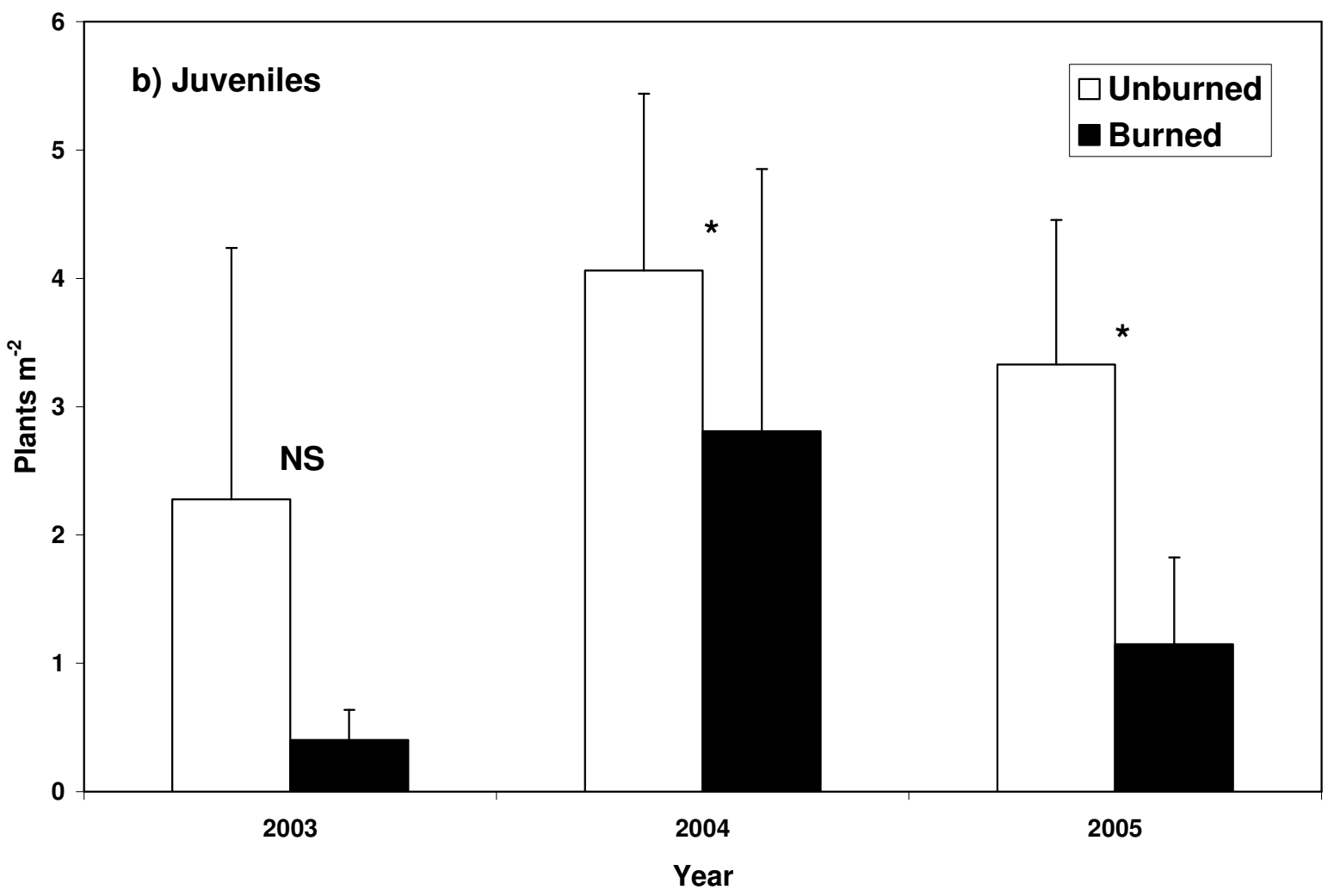




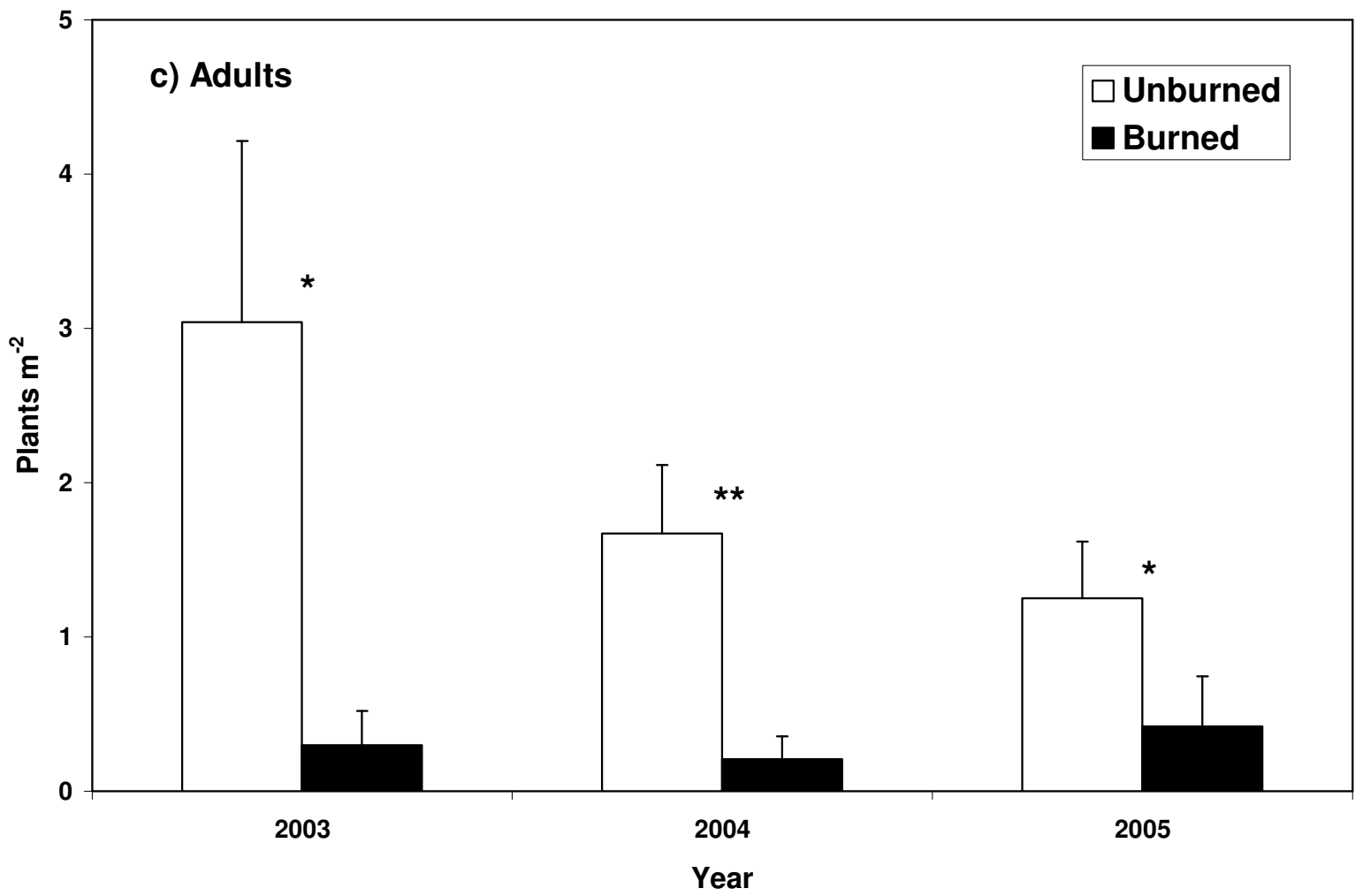




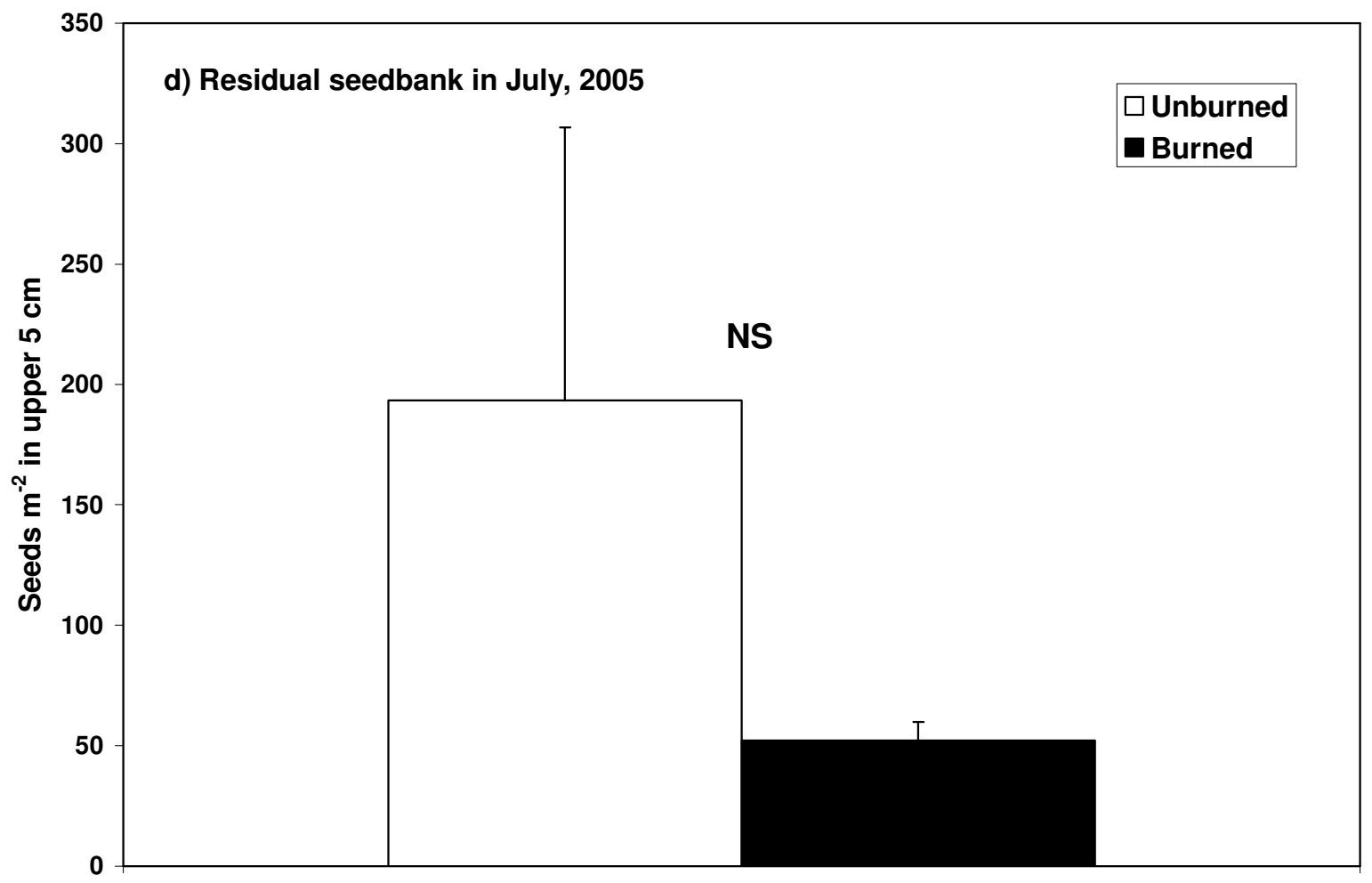

